Combating Domestic Abuse in Jordan from the Top-Down: Liberal and/or Democratic Statebuilding?

Jessica Watkins

Middle East Centre, London School of Economics, London, UK

TW1.10.01, Clement's Inn, London, WC2A 2AZ, UK.

Tel: +44(0)20 7955 3625; Email: J.Watkins2@1se.ac.uk

Jessica Watkins has been a Research Officer at the Middle East Centre, London School of Economics, since mid-2017. Her PhD was on civil policing in Jordan, and was completed at King's College London 


\section{Combating Domestic Abuse in Jordan from the Top-down: Liberal and/or Democratic Statebuilding?}

This article explores the premise that liberal statebuilding often produces unexpected results, through an examination of Jordan's campaign against domestic abuse. Over the past two decades, Jordan has become a regional leader in combatting domestic abuse, and its Family Protection Initiative is a prominent example of the executive's implementation of externally-supported measures promoting women's empowerment. However, ambiguities over the Initiative's central mission (i.e. to protect victims from re-abuse or to preserve the family unit) have meant that the state routinely pressures victims to reconcile with abusive family members. Here, I explore the context of the Initiative's development and argue that it reflects regime survival strategies, designed to deflect international pressure for greater democratic reform, to co-opt the Jordanian women's movement, and to circumvent Islamist and tribal opposition. I further argue that the common accusation by political opponents that the Initiative is 'foreign' is largely a veiled criticism of the executive for politically marginalising them and/or encroaching on their authority in family matters.

Keywords: liberal statebuilding, democracy, domestic abuse, hybrid regimes 


\section{Introduction}

The Hashemite Kingdom of Jordan has co-operated with an array of externally-sponsored democracy strengthening initiatives over the past two decades. Amongst them, the promotion of women's empowerment is one of the most highly publicized, and in some respects, one of the most productive fields, with a series of legal reforms passed to further the position of women in society. Despite this, Jordanian women languish near the bottom of the Global Gender Gap assessment overall, and rank particularly poorly in terms of economic status (World Economic Forum 2018). ${ }^{1}$

There are various possible explanations for this state of affairs: that Jordan has been under immense socio-economic pressure during those two decades and that women have borne the brunt of suffering; that despite the monarchy's best efforts, resistance to women's rights by conservative Islamist and tribal forces is stymying progress; conversely, that the regime and/or its Western allies are not really interested in pursuing the substantive political reforms which are needed to underpin women's rights because their political agenda is focused elsewhere. There is also the possibility that democratic statebuilding efforts related to women's rights have stalled because international and domestic actors have different ideas about what they look like and how they should be achieved.

Commenting on the disparity between the stated objectives of democracy promotion programmes in Jordan and their outcomes (i.e., reconfiguring authoritarian rule), Benjamin Schuetze notes that interventions often tell us more about the intervener than the environment that is intervened upon (Schuetze 2018: 240). He takes the case of Western aid agencies pursuing parliamentary strengthening measures based on a market-based 'supply and demand' logic. In an effort to depoliticise interventions, they offer technical expertise aimed at improving parliamentary efficiency and democratic oversight, overlooking the actual logic 
of power pertaining to the Jordanian parliament (as a patronage provider and a democratic façade) and thereby further contributing towards authoritarian upgrading. Schuetze relates his enquiry to a 2013 study by Meera Sabaratnam, which analyses how assumptions of Eurocentric distinctiveness and superiority are reified even by postcolonial critics of liberal peacebuilding because they cannot break free of the colonising ontologies of Western political theories. She argues that Eurocentricism emerges even in critical peacebuilding studies that ignore the perspectives of the recipient population, or assume that they are passive recipients of the logics and/or material effects of intervention. She also notes a tendency in critiques of the liberal peace to assume 'an ontology of cultural 'Otherness' via the 'liberal'/'local' divide (Sabaratnam 2013: 263). Sabaratnam acknowledges the difficulties of avoiding the 'trap' of Eurocentric assumptions but suggests that observing certain methods of enquiry can help to decolonize the study of intervention.

Like other postcolonial critiques, Sabaratnam's argument is open to the accusation of being ultimately anti-foundational, and here I take a more sympathetic view of the dilemmas facing statebuilders in their pursuit of the elusive common good. In framing my analysis of Jordan around the normatively charged concept of the 'hybrid regime', I do not pretend to free myself entirely of Eurocentric thought. Moreover, unlike many assessments of Arab governance, I do not assume that the Jordanian monarchy's bids to strengthen women's position of in society are disingenuous. But Sabaratnam's study provides a useful lens through which to observe how a 'postcolonial encounter' (Sajed 2013) between the intervenors and the intervened upon is instantiated in Jordan. Rather than focusing exclusively or even primarily on the objectives of external statebuilding actors (an approach which inevitably side-lines the agency of domestic actors), I shift the lens towards the context of intervention. This shift necessitates consideration of the perspectives of aid 'beneficiaries' (whether implementing partners, political critics or the 'objects' of intervention) and breaks 
down perceived dichotomies between liberal Western statebuilders and reactionary Eastern societies, shedding light on how intervention takes shape and often produces unexpected outcomes.

The paper investigates a particular sphere of statebuilding in the Kingdom, the empowerment of women. Frequently presented as a cornerstone of liberal democratic statebuilding, gender equality is also broadly recognised as a sphere in which cultural 'Otherness' prevents possibilities for meaningful cooperative reform. At the same time, however, 'hybrid' regimes such as Jordan are often willing to promote aspects of women's rights precisely because they do not shake the foundations of their rule (Tripp 2013; David \& Nanes 2011). One particular area of women's empowerment in Jordan which has resulted in an ambiguous, and arguably undesirable outcome for statebuilders is the campaign to combat domestic abuse which dates to the late 1990s. Far from being passive or unwilling recipients of intervention, the monarchy has fronted the campaign. Jordan has undertaken a series of measures within the auspices of the Family Protection (Himayat al-Usra) Initiative to reduce violence against women and children in the home. These include public outreach campaigns, the provision of legal advice, counselling, medical and protection services to victims, and legal reforms to increase punishments that can levied on perpetrators. These varied initiatives have drawn in external and Jordanian state, non-state and semi-state actors whose overall impact on society is multi-dimensional and complex. Nonetheless, the emphasis of the statedriven campaign on preserving the family unit has arguably led to an ambiguous legal situation in which victims who seek help from the police Family Protection (FPD) Department are routinely pressured into being 'reconciled' with abusive family members. This raises questions about whether the initiative's 'real' objective is to protect the family, or to protect the family name. 
The paper seeks to understand the guiding influences in the Family Protection campaign, and whether resistance to it has primarily been a result of an East/West 'clash of cultures', as it is often characterized by those who oppose it - and, indeed, by some who support it. I argue that the campaign has highlighted normative confrontations, but that these cannot be reduced to liberal individualism versus conservative Islamism, or to an East versus West dichotomy. Nor can they be reduced to an overarching binary between the international and the (much touted) 'local' (Ginty 2011; vs, Hirblinger \& Simmons 2015). In important respects, clashes reflect domestic political trends. Notwithstanding international development agencies' involvement in the campaign, its impetus and design (which in many respects is paternalistic) has been shaped primarily by the monarchy. The campaign's trajectory reflects the monarchy's bid to co-opt women rights' groups and causes on the one hand, and to circumvent opposition from tribal and Islamist factions on the other. International development agencies perpetuate this dynamic by supporting top-down reform.

The paper's assessments rely on a combination of oral testimonies, policy memoranda and legal provisions. On the one hand, I refer to publications issued by international development agencies. On the other, I draw on semi-structured qualitative interviews conducted in person in Jordan and by telephone between 2011 and 2018. Interviewees included the director and an external relations representative of FPD; the lead coordinator with the FPD from the Ministry of Social Affairs; a spokesperson for the Jordanian National Centre for Human Rights; three spokespeople at the National Council for Family Affairs (NCFA); over a dozen publically recognized tribal 'elders', a spokesperson for the Muslim Brotherhood, a British diplomat and former consultant who were involved in setting up the FPD; and the Presidents of Mizan Law Group for Human Rights, the Jordan Society for Protecting Family Violence Victims (JSPFVV), Sisterhood is Global (SIGI) Jordan; and a legal counsellor for the Jordan Women's Union (JWU). I also draw on interviews conducted 
with over 30 Jordanian women, including several who acknowledged they had been victims of domestic abuse, from different socio-economic backgrounds across Jordan, whose views I sought in my broader research into the role of the Jordanian police in dispute resolution processes. Where interviewees are identified it is because they consented for them to be used in academic research on combating domestic abuse. It should, however, go without saying that my assessments here do not necessarily reflect the views of my interviewees.

The discussion unfolds in four parts. The first assesses the problems associated with liberal statebuilding models which have attempted to incorporate gender empowerment into interventions from above. Recognising the centrality of the Jordanian monarchy in leading the campaign against domestic abuse, the second part shifts to the domestic outlook by situating Jordan's pursuit of liberal reforms and particularly the promulgation of women's rights post-1989 in the literature on hybrid and aid-dependent regimes. Part three explores the trajectory of the Family Protection Initiative from 1997 and specifically the FPD's remit. The final part assesses how the relationship between the main stakeholders (the regime, Jordanian women's groups, and international development agencies) has shaped the campaign's focus on reconciling victims with their families, and suggests that opposition voiced by tribal figures and Islamists reflects contestation over societal norms but also political priorities.

\section{Women's Empowerment as a Cornerstone of Liberal Statebuilding}

Calls for worldwide gender equality have been evident in the United Nations' agenda since the 1970s. In 1979, the UN General Assembly adopted the Convention on the Elimination of All Forms of Discrimination against Women (CEDAW) - an international bill of rights for women that defines discrimination and sets up an agenda for national action to end it. The implementation of CEDAW in the Global South became increasingly relevant from the 1990s 
amidst a climate of liberal interventionism by Western and multilateral development agencies. In 2000, UN Security Council Resolution 1325 called for 'women's equal participation and full involvement in all efforts for the maintenance and promotion of peace and security'. And in 2011, international partners in the New Deal for Engagement in Fragile States declared that 'The empowerment of women ... is at the heart of successful peacebuilding and statebuilding.' While early formulations of statebuilding focused on 'failed' states, whereas peacebuilding focused more narrowly on post-conflict states, both terms were increasingly applied to measures taken in more broadly construed 'fragile states', including a number whose central governmental structures remained intact (e.g. Grävingholt, Gänzle, and Ziaja 2009; Chandler 2010). Development agencies including the US Agency for International Development (USAID), the Organisation for Economic Co-operation and Development (OECD), and the UK Department for International Development (DFID) have subsequently sought to highlight how gender could be 'mainstreamed' into all statebuilding activities (e.g. OECD 2013; Domingo \& Holmes 2013).

Yet, the pursuit of gender equality is one of the most problematic components of the liberal peace agenda. Mark Duffield describes this agenda as:

...a new or political humanitarianism that lays emphasis on such things as conflict resolution and prevention, reconstructing social networks, strengthening civil and representative institutions, promoting the rule of law, and security sector reform in the context of a functioning market economy. In many respects, while contested and far from assured, liberal peace reflects a radical developmental agenda of social transformation (Duffield 2001: 1011).

In fact, as Hutchings argues, liberal internationalism has become associated with principles and practices that are frequently in tension with one another: human rights and rights to national self-determination, neoliberal markets and commitments to development aid, state 
sovereignty and responsibility to protect (Hutchings 2013: 160). And yet, at 'the heart of any position that calls itself liberal [is] the valorisation of individual freedom' (Ibid).

This apparent commitment to individualism is frequently conceived as the source of enduring tension between atomistic 'Western' and 'Other' cultures, and whether gender equality is particular to liberal democracy or a fundamental feature of any democracy is disputed. 'Are emancipation, equality, and rights part of a universal language we must use?' asks Lila Abu Lughod rhetorically (2002: 788). In the Middle East and North Africa (MENA), most states have signed CEDAW but applied reservations to several clauses. Religious arguments (and especially Quranic verses 2:228, and 4:434), are commonly cited as grounds for treating men and women unequally, particularly within the context of marriage. This was, for instance, very apparent in Jordan in 2003 when Islamist members of parliament blocked proposed amendments to personal status law, citing the amendments' incompatibility with the Shari'a (Clark \& Young 2008: 347-348).

Arab women's rights activists, most of whom identify as Muslim, argue that these verses can be interpreted as a comment of their time (i.e. 1,500 years ago) as opposed to a prescriptive dictate; and that Islam is being exploited by authoritarian rulers and influential societal figures as a pretext to justify patriarchal norms (e.g. Chaudhry 2016: 23). The fact that women's rights are more established in several less patriarchal non-Arab Muslim countries appears to support this argument. Even so, repeated public polling across the Arab world indicates that while the large majority favour democratic governance, they are less categorical about gender equality. The 2017-2018 Arab Opinion index indicated that 76 percent of Arabs believed democracy was the most appropriate system of government. But a 2012 Gallup poll across six Arab countries indicated that while 75 percent of men and women agreed they should have equal legal rights, slightly less than 50 percent believed that women should be equally entitled to initiate a divorce. A 2017 Promundo/UN Women poll in 
Egypt, Lebanon, Morocco and Palestine indicated that 74 percent of men and women believed that men should have the final say within the home and over 80 percent believed that women should tolerate violence in order to keep the family together (Promundo/UN Women 2017: 47)

Different attitudes towards the role of women in society, then, cannot be dismissed as barriers to introducing measures that 'empower' women, in the Western sense. But the premise of 'Otherness' can also be used to distract from the fact that Western-centric statebuilding measures in the Middle East are predominantly framed as top-down interventions which, in many cases, are reframed and/or manipulated by undemocratic elites to serve domestic objectives. Although Western development agencies rhetorically embrace the merits of working with civil society as means of promoting democracy from the bottomup, they have narrowly construed civil society as non-governmental organisations, which in the MENA context are normally under the control of the executive (e.g. Jad 2003). In a damning appraisal of Western intervention in the Muslim world ('Do Muslim women Really Need Saving?), Abu Lughod highlights the Western preoccupation with understanding the 'culture' of the Middle East, and particularly its religious beliefs and treatment of women, as opposed to understanding the history of repressive regimes and the role of the US in the region (Abu Lughod 2002: 784). She suggests that during the US campaign to liberate Afghan women from the Taliban in 2001, the degree of sympathy expressed by American and European women for Afghan women was based on a sense of pity and smug superiority that Western women felt for 'oppressed Muslim women' (Abu Lughod 2002: 787).

Elsewhere, she argues that Western pressure on Muslim governments to improve the status of women could be undermining the local legitimacy of feminist causes (Abu Lughod 2013). In a similar vein, Sheila Carapico's chapter on 'Patronizing Women' picks up on 'a phrase bantered among bilingual development professionals about being "caught between the 
paternalism of Arab men and the patronizing of Western feminists"' (Carapico 2015: 113). Carapico highlights the Orientalist tendencies of post-colonial aid implementers to repeat 'stock phrases like 'patriarchal culture' that are not investigated empirically so much as 'known in advance' to characterise native pathologies' with no western analogies (Ibid: 115).

Both critiques resonate in Jordan's campaign against domestic abuse. On the one hand, Western statebuilding interventions have indeed been advocated in terms of the supposedly universal values of liberal individualist humanitarianism, and have equally been denounced by political Islamists and tribal figures who argue that they do not cohere with Islamic law or with Jordanian values. My own empirical investigations into the campaign suggest that patriarchal norms are a major barrier to societal acceptance of state intervention into the family sphere. On the other hand, however, the executive's firm control over most domestic NGOs, coupled with the Western (particularly US) prioritisation of geostrategic concerns and fear of political Islam, have led to external promotion of women's rights being primarily channelled through the monarchy and thereby shaped by its survival strategies. This in turn has alienated opposition voices, who have arguably used hostility to 'foreign interference' as a pretext for resisting an initiative which reinforces the authority of the regime at their expense.

\section{Jordan in Perspective: Women's Rights under Hybrid and Aid Dependent Regimes}

\section{Regime Hybridity \& State Sponsored Feminism}

Jordan's history of grassroots women's activism dates back to the establishment of the Jordan Women's Union (JWU) in the mid-1940s. Even so, the executive has long constrained nongovernmental organisations including women's groups, and, with international 
encouragement, has fronted or co-opted most initiatives promoting women. In this light, a discussion of women's rights in Jordan needs to be prefaced with an account of regime hybridity, aid-dependency, and the geo-strategic prerogatives of donors.

Hybrid regimes are 'ambiguous systems that combine rhetorical acceptance of liberal democracy, the existence of some formal democratic institutions and respect for a limited sphere of civil and political liberties with essentially illiberal or even authoritarian traits' (Ottaway 2003). While some see them as transitioning towards fully functioning democracies, others take them to be using the trappings of democracy as survival strategies to upgrade authoritarian rule (Brumberg 2002; Heydeman 2007; Brownlee 2009). In the MENA, regimes including Morocco, Kuwait, Tunisia, Egypt and Jordan took a series of liberalising measures in the early 1990s (e.g. Ehteshami 1999; Anderson 2001). In addition to economic reforms, these included extending freedom of speech and assembly, legalising political parties and holding legislative elections. But in every case, rulers retained control over the executive and legislative process. By the late 1990s, "it became evident that few of these processes would live up to their promises, as openings were reversed or manipulated in ways that made talk of progress toward democracy ridiculous' (Ryan \& Schwedler 2003: 140). Renewed optimism that the 2010/2011 Arab Uprisings would compel regimes to redress social contracts with citizens was short-lived as moves to enhance civil liberties, reform electoral and constitutional laws were broadly dismissed as superficial (Heydemann 2012; Aziz 2017).

State-sponsored feminist policies are common in hybrid regimes (Errazzouki \& AlKhawaja 2013; Wilde et. al. 2018). They often include introducing women's quota seats in elections; securing women better access to education; promoting women's associations to operate as core components of civil society (which is broadly controlled by the state in any case); or raising the profile of select women in public life (Muriaas, Tonnessen \& Wang 
2013; Tripp 2015). Lorch \& Bunk argue that authoritarian state feminist policies fall into three survival strategies: legitimation (i.e. improving the regime's own image in the eyes of its public and/or the outside world); co-optation (supporting women's causes to win votes or moral support); and a form of divide-and-rule whereby secular women's rights groups are played off against Islamist groups (Lorch \& Bunk 2016: 6). The latter strategy is evident in several MENA countries, where regimes have promoted women in some spheres but retained conservative personal status and inheritance laws which discriminate strongly against women (Al-Ali 2002: 9; Salhi 2010).

\section{Aid Dependency \& Democratic Reform}

As to the extent of international influence on reform, external actors logically have greater leverage over gender policies in states which depend on their aid. In the 1990s, Western states began trying to link aid directly to democracy promotion in 'fragile' states. US democracy promotion peaked during the Clinton and Bush administrations, and in 2006, Condoleeza Rice announced the State Department's initiative to link aid to 'transformational diplomacy' aimed at bringing about sustainable democracy abroad (Rice 2006). The prospect of Western development aid has indeed motivated pro-women reforms in some states (Adams 2007; David \& Nanes 2011; Tripp 2013). However, the effects of democracy strengthening aid are often obscured by bilateral military assistance. Where recipient regimes have particular geo-strategic value as allies - as is the case with Jordan - democratisation attempts are confined to less politically sensitive initiatives, such as offering technical expertise to members of parliament or human rights training to security agencies, and statebuilding efforts have been predominantly channelled through the regime as opposed to grassroots agencies. 
In Jordan, aid dependency and regime hybridity have gone hand-in-hand since the 1989 economic collapse. The Kingdom's foreign policy has historically sought to maximise external aid and investment (Brand 1995). Since gaining independence from Britain in 1946, and notwithstanding several diplomatic hiccups, the executive has capitalized on its role as a vital strategic ally to the US, European states, and the Arab Gulf to attract foreign grants and investment. Even at the height of the oil boom in the 1970s and 1980s when the economy was buoyed by remittances sent by nationals working in the Gulf, aid was a staple source of income. After the oil price collapse in 1986, the US, the International Monetary Fund (IMF), the World Bank, and the UN became increasingly important in this regard. In 1989, the executive appealed to the IMF to bail the economy out. In return, the IMF demanded cuts in government spending and fiscal reforms to increase domestic revenue. The subsequent political opening up (Infitah), during which martial law was lifted, political parties legalised, and legislative elections held reflected the government's recognition that imposing fiscal austerity required some compensatory civil rights concessions (Brand 1992; Brynen 1992).

A public backlash against Jordan's 1994 peace agreement with Israel is credited with halting liberalisation under King Hussein (Brand 1999). On accession in 1999, King Abdullah II adopted the role of moderniser, and throughout the 1990s and early 2000s, signalled enthusiasm for democratic reform (at least to Western audiences). Onlookers questioned whether the country was headed towards democratic government. Some noted that the Royal Court had deliberately undermined grassroots movements by co-opting civil society (Brand 1999; Wiktorowtz 2000; Nanes 2003). Others dismissed the significance of elections, pointing to the regime's successive gerrymandering of electoral constituencies, and to the fact that members of parliament exercised no substantive power. Rather, the purpose of elections was to provide a basis for the distribution of patronage (Lucas 2003; Lust, Hourani, \& El-Momani 2011). 
A defining feature of Hashemite rule has been its patronage of the 'native' Transjordanian population. Tensions between Transjordanians and Palestinians who came to the country after the 1948 and 1967 Arab-Israeli Wars crystallised in the late 1960s and the Palestinian-Jordanian population has been marginalised from the public sector. Post-1989, successive changes to parliamentary electoral rules have disproportionately favoured loyalist tribal heartlands at the expense of large urban centres where Palestinian-Jordanians are concentrated. Political parties are weak, with the exception of the Islamic Action Front (IAF) (the Muslim Brotherhood's political wing, which has a strong Palestinian-Jordanian support base), and the vast majority of parliamentary representatives are independents. Under King Hussein, the Brotherhood acted as the 'loyal opposition'. However, Abduallah's relations with the Brotherhood have deteriorated since 2005 and the executive has used the threat of Islamist political gains to deter donors from pressing for radical political reform. In 2013, the executive outlawed the Brotherhood's dominant 'hawk' wing, granting a licence instead to a more compliant offshoot ('dove') group.

Royal patronage has been inconsistent. Some East Bankers have enjoyed considerably greater favour than others over the years, but not all Palestinians have been excluded (e.g. Greenwood 2003; Peters \& Moore 2015). Increasingly under Abdullah, patterns of patronage have given way to neo-liberal economic reforms which have alienated large segments of the Transjordanian support base by cutting public sector employment, commodity subsidies and welfare perks, concentrating them instead in the hands of the military and their dependents (Baylouny 2008). Disgruntled East Bankers, as well pro-Islamist Palestinian-Jordanians, were amongst the most persistent protestors against corruption, socio-economic injustice and claimants of political reform during the Arab Spring protests in 2011-12 (Yom 2014).

The King responded to mass demonstrations in 2011 by sacking the government and promising extensive reforms. Various measures were subsequently introduced: over 40 
constitutional amendments were passed; a new electoral law increased parliamentary seats from 120 to 150 , of which 18 percent were to be elected through countrywide party lists; and the King promised to appoint prime ministers in consultation with parliament. These measures scarcely diminished overall royal control. Moreover, the government incrementally curtailed freedom of expression, for instance with the 2012 Press and Publications Law, which attempted to silence websites that criticised the government, and further restricted NGO autonomy in 2015 by requiring that they obtain governmental approval before receiving foreign funding. The executive indicated that much as it favoured democratic process, the people were unprepared for wholescale democracy and needed to be guided from above King Abdullah 2013; Al-Samadi 2013; Charbel 2014; Martinez 2017).

Jordan's external benefactors have broadly accepted the argument of political immaturity. USAID sees Jordan as 'a voice for moderation, peace and reform in the Middle East' whose internal collapse is unconscionable (USAID Jordan 2019). Jordan's assistance to the US regional war on terror, its willingness to host several million Iraqi and Syrian refugees, and to cooperate with Israel make it a vital strategic ally. Jordan has become the third largest global recipient of US aid after Afghanistan and Israel. Between 2015 and 2017 it was allocated \$1 billion in annual US bilateral economic assistance (Sharp 2017: 13), and was excluded from US budgetary cuts to the MENA in 2018. Even at the height of liberal interventionism, democracy promotion came a distant second to boosting the state's military capabilities: between 2004 and 2007, USAID's democracy and governance assistance accounted for only 4\% of total US development assistance to Jordan (Peters \& Moore 2009: 279). Even so, Jordan receives far more 'pro-democracy' funding than other MENA states. The US government spent $\$ 88.2$ million on democracy and human rights programmes in Jordan between 2013 and 2015 alone; nearly \$10 million more than on similar programmes in Lebanon, Libya, Morocco, Tunisia, and Yemen combined (McInerney \& Bockenfeld 2017). 


\section{Hashemite Patronage of Women's Rights}

Hashemite policies on women's empowerment have been amongst the most obvious markers of political liberalisation and have been eagerly supported by international development agencies. In the 1990s, Queen Noor became a figurehead for women's and children's rights. Princess Basma bint Talal and the current Queen (Rania) have latterly adopted the cause. Jordan has signed several international rights conventions and taken steps to bring domestic laws into conformity with those conventions. In 1992, Princess Basma set up the Jordanian National Commission for Women ( $\mathrm{JNCW})$ with the purpose of:

...mainstreaming... a gender-equality perspective in all policy areas and narrowing the gap between formal acknowledgement of women's rights as detailed by legislation and actual societal attitudes towards women (JNCW 1992).

The government ratified CEDAW the same year, albeit with reservations on Articles pertaining to women's rights within the family on the grounds that they contravened the Jordan's Personal Status Laws which are based on Sharia.

Since Abdullah's accession, the monarchy has advocated several amendments to the Criminal Code and Personal Status Laws. Some have been ratified: in 2002, for instance the government raised the minimum marriage age to 18 for men and women from 16 and 15 respectively (albeit with mitigating conditions). In 2017, parliament finally voted to abolish the law exempting rapists if they married their victims. Other proposals (for instance, pertaining to women's rights to initiate divorce and to claim compensation) have been repeatedly rejected by both 'Islamist' and 'tribal' components of the Lower House (Clark \& Young 2008). Indeed, this is one of the few areas in which parliament has effectively thwarted the executive, which has resorted to introducing reforms via temporary laws which 
do not require parliamentary ratification. Proposals to amend Articles 340 and 98 of the Criminal Code, which reduce the punishment for men who kill or attack female relatives who commit adultery, have also been rejected by the Lower House despite royal backing. MPs argued variously that the proposed amendment was evidence of foreign influences attempting to interfere in Jordanian society, and that cancelling the law would contribute towards the moral decay of Jordan's traditional and 'religious' society (Nanes 2003: 125).

Politically, in keeping with the Millenium Development Goal, in 2003 Jordan reserved six seats in parliament for women, rising to 12 in 2010, and to 15 in 2013. In 2007, a 20 percent threshold was guaranteed for women in the municipal elections, rising to 25 percent in 2011. The practical impact of these reforms is unclear. Arguably, granting women a parliamentary quota does not amount to politically empowering women when parliament has little power. Rather, it is a means of incorporating a select few women into the parliamentary patronage system (e.g. David \& Nanes 211). At the municipal level, small tribes can achieve big gains by strategically nominating women members to stand, even if they have no intention of using their seats to promote women's causes (Bush \& Gao 2017).

What is clear is that women's position trails that of men in several respects, and particularly with regard to income. Despite having amongst the best levels of education in the MENA and higher rates of university attendance than men, only around eight percent of women are employed, with a further seven percent seeking employment. Private sector companies often circumvent obligations to offer paid maternity leave and day-care for working mothers (Freedom House 2016). Jordanian inheritance laws, in keeping with Shari'a, stipulate than women are entitled half the inheritance that their brothers receive, but according to Freedom House, women are often denied access to even this share by male relatives (Ibid 2017). Moreover, in 2017 alone, over 1,100 women victims of domestic 
violence and/or at risk of being the targets of 'honour crimes' were being held indefinitely in prisons under administrative detention for their own 'protection' (Jordan Times 2017).

\section{The Story of Jordan's Family Protection Initiative}

\section{Origins and Effectiveness of the Campaign}

Domestic abuse against women - defined as physical, sexual and psychological violence by any family member - is prevalent in Jordan. Data is admittedly scarce due to definitional discrepancies, under-reporting and the lack of a coordinated national database. However, public polling has produced indicative findings. In 2009, research by Clark et al. suggested that almost a third of married women had suffered from intimate partner physical violence, and almost 19 percent from sexual violence. A 2012 national representative survey by the Demographic and Health Study (DHS) of 11,352 ever-married women aged 15-49 across indicated that 32 percent had experienced emotional, physical, and/or sexual violence from their spouse, and 22 percent reported having experienced one or more forms of violence in the past 12 months (DHS 2013: 199). ${ }^{2}$

Petitions for enhanced legal and practical protection measures for victims of domestic violence in Jordan have proliferated over the past 30 years. The Jordanian Criminal Code does not explicitly refer to domestic violence, although provisions within it can be invoked to prosecute sex attacks and 'immoral advances', serious cases of assault and exploitation. In 2010, amendments to the Criminal Code increased penalties for rape, molestation, and homicide, but the Code omits mention of violence (including rape) committed by a man against his wife. Criminal courts require plaintiffs to produce two witnesses in order to rule on wife battery. The principle sources of legislation relating specifically to domestic abuse are the 2008 and 2017 Laws on Protection from Domestic Violence discussed below. 
Practical state-led measures to combat abuse began with the establishment of the Family Protection Unit (later transformed into a Department - the FPD) as a branch of the Public Security Directorate (police, or PSD) in 1997. The trigger for developing this unit seems not to have been domestic abuse, but rather a rape case of British/Iraqi woman by a stranger the following year. A British employee of Prince Hassan (then Crown Prince), took the issue to the British Embassy (with Hassan's approval). As a result, several British police officers were sent to Jordan to run a course for the Jordanian police on how to deal with sexual crimes. Interest grew in establishing a unit modelled on the Child Protection and Domestic Violence Units run by Social Services in the UK. In 1999, UK DFID invested $£ 2,500,000$ into a 'Family Protection Programme', a holistic initiative drawing in the police but also the Ministries of Justice, Social Development, Health, and a number of independent experts and NGOs. ${ }^{3}$ The participants were initially divided into task-force committees, focusing on legal or medical issues or public relations etc. ${ }^{4}$

While the FPD is directed by the police, it is also staffed by social workers from the Ministry of Social Development, medics, psychologists and members of the Jordan River Foundation (a Royal NGO set up by Queen Rania). Since 2007, the Ministry has run the Dar Al-Wefaq al-Osari shelter in Amman for the worst abuse cases, with capacity to accommodate 50 women with 36 accompanying children. In 2015 it opened an additional government shelter in Irbid able to accommodate 25 women and up to 12 children.

The FPD's reach and remit has increased incrementally. Initially restricted to Amman, the department now has branches in all provinces barring Ma'an. The FPD deals with walkins and referrals as well as manning a national complaint hotline, and handles offences categorized as legal violations (mukhalafat) involving minor injuries, and also more serious criminal felonies (janayat) that result in incapacity for over ten days. While felonies must be referred directly to the public prosecutor, the FPD can take several incremental steps with 
respect to violations. After an initial report of the incident has been generated, an investigation is launched, along with a physical examination of the victim if necessary, followed by a social follow-up and reconciliation process. On a plaintiff's request, the FPD can transfer cases to the courts for prosecution, and where victims are deemed to be at continued risk, it can refer them to government shelters. The FPD also runs preventative outreach programmes which include delivering educational lectures in schools and training district police in 'basic family protection skills' so they can recognize abuse cases and refer them to the FPD (Interview with FPD spokesperson for external relations, April 2012).

Several Jordanian NGOs work closely with government agencies as part of the Family Protection Initiative. The Jordan River Foundation (JRF, established 1995) seconds employees to the FPD and since 2000 has run a shelter in Amman for up to 32 child abuse victims. Mizan Law Group for Human Rights (established 1998), provides legal aid to women referred to it by the FPD, and equally refers cases requiring heightened protection to the FPD. The two organizations co-ordinate to train agencies on family protection skills. Rim Abu Hassan, the ex-President of the JSPFVV (established 1998), who became Minister of Social Development between 2013 and 2017, indicated that her charity had a strong working relationship with the FPD based on mutual trust between individuals in both organizations. The oldest women's society in Jordan - the Jordan Women's Union (JWU), originally founded in 1945, has a more contentious relationship with the FPD but its shelter for abused women sometimes takes referrals from the police.

In 2008, the legislature passed the Protection from Domestic Violence Law. The law covered the practice of dealing with domestic abuse, specifying actions to be taken by the FPD, medical professionals, the Ministry of Social Development, courts, etc, and punishments that could be prescribed. It also stipulated that with the agreement of the victim and alleged abuser, the Minister of Social Development was empowered to recommend the 
formation of a multidisciplinary Family Reconciliation Committee charged with reconciling family members in cases of violations and thus averting the need for court proceedings. The reconciliation committees never materialized because the procedure for convening them was unclear and authorized the police to dismiss cases that only the public prosecution is empowered to dismiss. An amended law was passed in May 2017, stipulating further possible punishments courts could apply and providing more detail on protective measures for victims and other family members. The law abolished the notional reconciliation committees, but stipulated that minor offenses (which it refers to as 'disputes' rather than crimes) should initially be resolved through a settlement process organized by the FPD, who would pass details of the settlement to the court to ratify or amend 'if necessary'.

In practice, the majority of cases are categorized as minor on the basis that they do not cause incapacity for over 10 days. As a result, victims are often pressured to agree to being 'reconciled' with abusive family members. While the Criminal Code enables women to sue for compensation from their abusers, and divorce laws now stipulate domestic violence as grounds for divorce, the overall institutionalised emphasis on reconciliation reflects rather than challenges underlying societal norms about women's obligations to their husbands, fathers and brothers. Lack of public data makes it impossible to judge whether proreconciliation counselling and mediation services are in fact reducing re-abuse rates, or actually making the situation worse for victims, as some of my interviewees suggested.

\section{Uptake of Services by Jordanian Women}

Statistics released by the FPD in recent years suggest that more Jordanian women are taking complaints to the department. ${ }^{5}$ But the numbers are still small, and smaller still as a percentage of the expanding population. A 2016 UN Women report indicated that only 3 
percent of women would seek police help if subjected to domestic abuse (UN Women 2016). While there is no consolidated database recording instances of abuse reported to different agencies, NGO representatives I spoke with suggested that a larger percentage seek help from civil society organisations, but that friends and other family members remain the main and usually only source of support.

My interviews with women in different parts of the country from varied socioeconomic backgrounds, whilst admittedly only comprising a scant sample, indicated that victims of domestic abuse believed it preferable to keep the issue to themselves. Although the sample size was insufficient to conjecture about the relative effect of wealth on women's choices in this regard, Jordanian NGO interviewees indicated that in their experience, women of independent means tended to be more assertive with the FPD about insisting on pursuing their legal rights, often because they were better equipped to cope with their husbands being financially penalised, or indeed to cope without their husbands' income. Conversely, one young women in Jebel Al-Nadhif, a poor, overcrowded, quarter of Amman, told me 'the losses [involved in reporting abuse] are greater than the gains'. Inhibiting factors cited included insufficient knowledge of the procedures and insufficient confidence in the sympathy, efficacy and/or discretion of the police. One disenchanted former member of the FPD commented on the agency's inability to address the real problems women face at the hands of their abusers, saying that all the department did was to write reports on the cases, call the women's husbands, and 'tell them to be nice'. By far the most prominent factor, however, was the underlying lack of societal support and fear of retribution from family members. The same, former FPD employee said: them if they know they have been there.... and many of them are actually punished by their brothers or husbands (Interview, Amman, April 2012). 
Members of victims' tribes have occasionally attempted to break into the Wefaq shelter, prompting local governors to send women at risk of further abuse to prison for their own protection (Interview with former employee of Prince Hassan, April 2011). And according to Jordanian NGOs who offer legal advice to victims, few of the women who do take complaints to the FPD seek prosecution. From a practical perspective, women gain nothing from fines levied by the state on their husbands, and indeed suffer doubly when the husband is the family's main source of income. Moreover, many cannot afford the expense of a court case. In the same way that they distrust the police, victims often lack faith in the justice system. More importantly, court cases require women to give detailed accounts of sensitive personal information and to publicly confront their abusers, who often bring family members for moral support. As a consequence, most cases handled by the FPD are settled 'amicably' without reaching court, reinforcing the state (and predominant NGO) narrative that their central mission is to protect the integrity of the family unit.

\section{Assessing Agendas, Outcomes \& Opposition to the Campaign}

...assaults on and abuses of children are prohibited, as well as any form of violence against women... (King Abdullah's speech, November 2008).

\section{The Stakeholders}

To appreciate how the FPD's role has developed as a part of the broader campaign, we need to consider how the main stakeholders (who can broadly be summarised as international development agencies, Jordanian women's groups, and the executive) have interacted, and 
how the main opposition voices (who can broadly be described as tribal figures and Islamists) have reacted.

Aside from DFID's initial role in setting up the initiative, numerous international development organisations including UN agencies, the EU, USAID, the World Bank, and the International Centre for Transitional Justice, have contributed to the Initiative. On the one hand, they have urged Jordan to sign international rights conventions such as CEDAW, advocated domestic legal reforms; and monitored their enforcement. On the other, they have provided technical assistance and training to both government agencies and Jordanian NGOs to offer particular services to victims and to run public awareness raising campaigns.

Most external governmental agencies have attempted to work with both the Jordanian authorities and non-state entities, whereas international NGOs target interventions predominantly (although not exclusively) through domestic NGOs. As noted, however, the executive exercises firm control over NGOs. Two key NGOs in the Family Protection initiative - the NCFA (an umbrella organization established in 2001 to coordinate governmental and non-governmental agencies working on family affairs) and the JRF - are NGOs by Royal Decree (RONGOs). And while some women's rights groups (for instance the JWU and JSPVV) have deliberately kept their distance from royal patronage, most have sought out members of the royal family have sought out members of the royal family to be their patrons. In interview, a British diplomat previously involved in establishing the FPD seemed to support this practice, saying:

...in general..., if you want to get something done in these hierarchical societies and particularly if it's potentially controversial and people aren't sure whether they should be doing it, then getting high level endorsement is key - because then you create a safe place, where people know they are encouraged to gather under that umbrella.... if you had their patronage... you had this general sense of endorsement that helped people to engage.... and if you had a problem that you couldn't unstick through the normal channels, you could 
go straight to the top to seek their help (Interview with former Deputy Head of Mission for Jordan, Damascus, April 2011.)

RONGOs are exempt from Society Law 58 for 2008 which states that NGOs must obtain approval from the Council of Minister for all foreign funding. This enables the executive to control the extent to which domestic NGOs can forge partnerships abroad and indeed, international sponsors have shown a strong preference for funding RONGOS (Echagüe \& Michou 2011: 15; Al-Nasser 2016: 7). Moreover, Asma Khader (the SIGI President) indicated in 2018 that obtaining foreign funding was becoming increasingly difficult: partly because many international NGOs had set up offices in Amman and were seeking to implement projects directly without local partners; partly because applying for external funding had become complicated and time-consuming, meaning that smaller grassroots NGOs were effectively unable to do so, and partly because donor priorities were short term and constantly shifting (Telephone interview, 18 July 2018).

All of these points reinforce the fact that Jordan's Family Protection Initiative has always been primarily shaped by the monarchy. Besides endorsements from Prince Hassan and King Abdullah, female members of the royal family play pivotal roles in the Campaign. Princess Basma is the President of Jordan Save the Children and the patron of SIGI Jordan. She also appointed the founder of Mizan and SIGI Jordan (Asma Kader) to be the Secretary General of the JNCW. And Queen Rania is a member of the UNICEF Global Leadership Initiative and the founder and patron of the NCFA and JRF.

The monarchy's decision to front the Family Protection Initiative enabled it to champion the type of women's rights that Western donors are urging, while regulating civil society initiatives that those donors might otherwise seek to patronize directly. In addition to controlling domestic NGOs' access to foreign funding, executive control over civil society enables the monarchy to use RONGOs to bypass internal state bureaucracy as well as the hostility shown towards the campaign by some of the entrenched elite. While the FPD is now 
recognized as a permanent fixture of the PSD, senior police officers in other departments are suspicious of it (the FPD's own external relations officer confirmed as much in interview in 2012), as are many members of parliament (Jordan Times, 18 April 2017).

To reduce grounds for criticism, the executive has emphasised the Initiative's primary purpose not as promoting the autonomy of the individual but as preserving the integrity of the family unit (which, incidentally, is also one of the stated goals of the Al-'Afaf Association, a charitable organisation pertaining to the Jordanian Muslim Brotherhood $\left.{ }^{6}\right)$. Endorsement for the Family Protection campaign from the Ministry of Pious Endowments and several authoritative religious figures has been key in this respect. Hence, it has always presented the campaign's core objective as the need to protect the family, in which women, as mothers, wives, sisters and daughters, play integral roles. According to the NCFA,

The aim is to curb domestic violence and secure a stable environment for all family members in line with the religious directives, the cultural heritage and the basic human rights principles (NCFA 2018).

A senior family protection specialist at the NCFA confirmed:

Our core goal is to protect family unity. Because you know the family in our society has an important place. So even in cases of violence we want to bring the family back together as one unit' (Interview, Amman, July 2013). Several Jordanian NGO representatives I spoke to criticized the FPD's dismissal of cases without recourse to the public prosecution because it overstepped their remit. Nonetheless, even women's organizations that provide legal representation to women offered justifications for prioritizing family unity: either because they believed in the inherent sanctity of the family unit, or that they deemed it necessary to win over public support for taking any protective action against abuse, or because they recognized that victims that pursued legal action could be socially ostracised, impoverished, and/or subject to revenge attacks from family members who felt they had shamed the family name. 


\section{Assessing the Opposition: A Clash of Cultures?}

Limited uptake of FPD services points to a continued lack of broad-based societal trust in the department. A 2012 Jordanian national government survey indicated that roughly 70 per cent of Jordanian women believed there are circumstances under which a man is justified in beating his wife (DHS 2013: 194). Whether or not women really believe this, the finding is indicative of patriarchal attitudes. Political opposition to the family protection initiative voiced in parliament and in public speeches - has not actually been voiced in terms of men's God given right to beat their female family members, but in terms of the state overstepping its remit by encroaching in the private sphere of the family, and, crucially, shaming the family name.

Presenting initiatives to protect women (and children) from violence as a bid to protect the family appears to have partially reduced opposition. A former spokesperson for the IAF (a 'dove' rather than a 'hawk') told me:

I think the FPD is necessary. Because women and children are often subject to violence and no protection is offered to them. Some don't have tribes [to protect them] - particularly in cities. So the police and the security apparatus must have a bigger role in protecting women and helping the weak - you know - children. Many families break apart and this is detrimental to children (Interview, Webda, September 2011).

Other political Islamists have proven less sympathetic to the FPD and the Initiative more broadly. The woman's component of the IAF was pointedly excluded from the campaign when it was launched 20 years ago. The JNCW and most of the dominant NGOs involved in the campaign are strong advocates of CEDAW, and since ratifying the Convention in 1997, have pushed for reservations against certain articles to be dropped. The 
IAF and the Islamic Centrist Party opposed the ratification and in 2009 initiated a countercampaign denouncing CEDAW as a 'foreign and new occupation tool of the West, which amounted to 'declaring war against Islam' (Muhtaseb, Brown \& Kayyali 2016: 730; AlJazeera Arabic 2009). The two parties argued that Islam teaches gender justice rather than equality (Barari \& Alatiyat 2010: 363). Their objections to CEDAW cannot be read explicitly as an endorsement of domestic abuse: the IAF stated in their 2007 electoral campaign that women 'should enjoy the right to choose their future husbands and the right to marital happiness free from coercion and violence' (Ibid: 376). But their objections to what they claim to be foreign interference concerning gender issues are recurrent.

Besides Islamists' objections, considerable opposition to the FPD emanates from figures who are supposedly closely allied to the monarchy. During my research on police cooperation with community leaders in Jordan, the police put me in touch with a handful of tribal representatives across the country with whom they and provincial governors worked closely, who took an overtly hostile position. In a rural village in Mafraq, a Bani Hassan tribal leader said of the FPD:

Nobodies go to it! Or those who don't care for their reputation. Because as soon as women go there, their cases become public, and their families are shamed. Most women would prefer even marital disputes to be resolved within the family, or if need be with intervention by the shaykh who can deal with this sensitively (Interview, Rihab, September 2011).

And in an interview with a royally-appointed tribal judge and his son, a civil lawyer, in Karak, the son stated hypothetically:

I am a lawyer so I know. A child might go and complain against his father: will that bring the family together? If the father gets sent to prison? Or if a wife complains against her husband? Will that bring the family together? (Interview, Muhay, September 2011). 
His father quipped that the FPD would more appropriately be called 'Tafkik al-Osra' (Breaking up the Family), than Himayat al-Osra (Protecting the Family)!' A shaykh appointed to the royal diwan in a suburb of East Amman told me:

...now women are trying to copy the West and be more individualistic. They're rebelling - they're being encouraged to inform against their families. We are naturally democratic as God created us. But now this Western democracy is invading us. We live honourably and openly... but you have to know where your limits are - you can’t just step on other people's rights and call that democracy (Interview, Marka, July 2011).

Comments by MPs opposed to the passage of the 2017 Law on Domestic Violence convey the same type of disapproval of invasive Western influence. One MP from Zarqa province commented:

It seems that legislators forgot that we are in Jordan and not in Sweden, and we copy and paste laws without being mindful of our identity... I do not deny the presence of domestic violence, but better measures should be taken (Jordan Times, April 18, 2017).

Political opposition to the FPD is frequently expressed in terms of its 'foreignness' even though international agencies have clearly not forced it upon the Kingdom. Criticism of foreign interference has, for many years, been a much 'safer' avenue of activism than open dissent against the executive. Increasingly, however, it appears that hostility for the FPD masks resentment against the monarchy based on political exclusion as well as the increasing marginalisation of traditional figures of patriarchal authority within society. Clark \& Young (2008) argue with respect to Jordanian Islamists' objections to changes in family law (in juxtaposition to Moroccan Islamists' acceptance of them), that while ideology cannot be discounted, the wider political context and the relationship of Islamist political actors with the 
monarchy and other political actors also plays a significant role. At the same time, independent interviews suggested that some East Bankers consider two of the figures most closely connected to women's rights causes, Queen Noor and Queen Rania, as relative 'outsiders' - Noor because of her American nationality, and Rania because of her Palestinian roots. Several East Bankers I spoke to in 2013 boldly dismissed the FPD as 'one of the Queen's projects'.

\section{Conclusion}

Taboos surrounding domestic abuse and moreover state intervention into family affairs are scarcely confined to the Middle East, and it is only in recent decades that public opinion in Western societies has swung firmly in favour of robust state action. ${ }^{7}$ Judging by top-down initiatives, Jordan is the regional leader in confronting these taboos. Backed by international development agencies, the executive has holistically drawn in government ministries and state agencies, as well as co-opting publicly respected religious figures and civil society organizations (albeit only those which support its Western-friendly approach) to promote a comprehensive programme for providing services to victims, changing the law, and attempting to bring the public on board. And yet, the overall effects have at best been ambiguous, and at worst compounded victims' suffering.

To some extent, the same barriers exist whenever and wherever the law precedes the norm. Attitudes - and vested interests - take time to change; and it is not the intent of this article to argue that top-down reform can never be effective. Jordanian women's fears of seeking state intervention against members of their own family are surely not so 'Otherly' from women everywhere. And, while measures taken in any society to combat abuse of women in the home are generally presented within the rubric of women's empowerment, they 
often have paternalistic connotations relating to protecting the weak. In Jordan, however, as in other Western-friendly 'hybrid regimes', the executive is substituting democratic reforms that would genuinely broaden public access to political decision-making with externally sponsored liberal rights initiatives to promote women's empowerment. That does not mean that its support to women is necessarily cynical, but because it is resisting broader democratisation in other spheres, its Family Protection Initiative is strongly influenced by the need to co-opt (in the case of women's groups) and/or circumvent (in the case of tribal figures and political Islamists) actors who are pressing for reforms.

The Hashemite promotion of women's rights is also integral to its claim that it stands behind progressive reform, and therefore represents the West's best bet for overseeing gradual controlled democratisation processes until Jordanian society becomes 'ready' for fullblown democracy. Divided opinion within the Muslim Brotherhood and other mainstream Islamist groups over women's status and outright hostility to the 'foreign' imposition of CEDAW has easily won over Western allies to the monarchy's case and equally fuelled their caution over promoting meaningful democratic reform.

We cannot know how the campaign might have played out if international actors had been willing and able to target interventions more directly through a larger range of grassroots actors and organisations including Islamist groups, or had not intervened at all. But as it stands, the FPD's emphasis on reconciling victims with their families reflects the reality that the state cannot otherwise guarantee the ongoing safety of victims who seek its protection without imprisoning them. 
${ }^{1}$ The assessment uses four indices measuring economic participation and opportunity, educational attainment, health and survival and political empowerment.

${ }^{2}$ By comparison, in 2017 the Crime Survey for England and Wales (CSEW) estimated that $7.5 \%$ of women aged 16 to 59 had experienced some form of domestic abuse within the previous last year https://www.ons.gov.uk/peoplepopulationandcommunity/crimeandjustice/articles/domesti cabusefindingsfromthecrimesurveyforenglandandwales/yearendingmarch2017

${ }^{3}$ Ibid.

${ }^{4}$ Interview with President of the Jordan Society for Protecting Family Violence Victims (JSPFVV), Amman, July 2011.

${ }^{5}$ The FPD releases figures only sporadically, and frequently combines numbers on women and child victims. However, this assessment is based on public reports pertaining to 2004; 2006, 2012 and 2013 for which the number of cases against women reported to the FPD was 396; 1764, 2100, and 2104 respectively (NCFA 2008; Al-Rai, May 5, 2017).

${ }^{6}$ See 'Afaf's facebook page, at: $\underline{\text { https://www.facebook.com/alfaf.society/info/?tab=page info }}$

${ }^{7}$ See, for instance, Carolyn Hoyle's work on the police intervention into domestic abuse cases in the UK in the 1990s (Hoyle, C. 1998, Negotiating domestic violence: Police, criminal justice, and victims, Clarendon Press, Oxford).

\section{References}

Abu-Lughod, Lila. 2013. Do Muslim women need saving? Harvard University Press, Harvard 
Abu-Lughod, Lila. 2002. "Do Muslim women really need saving? Anthropological reflections on cultural relativism and its others." American anthropologist 104 (3): 783-790.

Adams, Melinda. 2007. 'National Machineries and Authoritarian Politics', in: International Feminist Journal of Politics, 9(2): 176-197

Alatiyat, Ibtesam, \& Hassan Barari. 2010. 'Liberating women with Islam? The Islamists and women's issues in Jordan.' Totalitarian Movements and Political Religions 11, (3-4): 359-378.

Anderson, L., 2001. Arab democracy: Dismal prospects. World Policy Journal, 18(3): 53-60.

Ayers, A. 2006. Demystifying Democratisation: The Global Constitution of (Neo)Liberal Polities in Africa', Third World Quarterly, 27(2): 321-338

Bush, Sarah Sunn, \& Eleanor Gao. 2017. 'Small Tribes, Big Gains: The strategic uses of gender quotas in the Middle East.' Comparative Politics 49(2): 149-167.

Brand, Laurie. 1992. 'Economic and Political Liberalization in a Rentier Economy: The Case of the Hashimite Kingdom of Jordan,' in Privatization and Economic Liberalization in the Middle East, eds. Iliya Harik and Denis J. Sullivan. Bloomington: Indiana University Press,

Brand, Laurie. 1995. Jordan's inter-Arab relations. New York: Columbia University Press.

Brand, Laurie. 1999. 'The effects of the peace process on political liberalization in Jordan', Journal of Palestine Studies. 28(2):52-67. 
Brownlee, Jason. 2009. 'Portents of pluralism: How hybrid regimes affect democratic transitions'. American Journal of Political Science 53(3): 515-532.

Brynen, Rex, 1992. 'Economic Crisis and Post-Rentier Democratization in the Arab World: The Case of Jordan,' Canadian Journal of Political Science 25: 69-96

Brumberg, Daniel. 2002. 'The trap of liberalized autocracy.' Journal of democracy 13(4): 56-68.

Carapico, S., 2013. Political Aid and Arab Activism: Democracy Promotion, Justice, and Representation (Vol. 44). Cambridge University Press.

Chaudhry, Ayesha. 2016. 'Interrogating the "Shari'a” Excuse: Religious Reasoning, International Law and the Struggle for Gender Equality in the Middle East in Valentine Moghadam (ed), Empowering Women After the Arab Spring. London: Palgrave Macmillan.

Clark, Janine \& Amy Young. 2008. 'Islamism and Family Law Reform in Morocco and Jordan', Mediterranean Politics, 13(3): 333-352.

Clark, Cari Jo, D. E. Bloom, A. G. Hill, and Jay G. Silverman. 2009. 'Prevalence estimate of intimate partner violence in Jordan.' Health Review of the Oriental Mediterranean, 15 (4): 880-889.

DAC-Development Assistance Committee. 2007. Principles for good international engagement in fragile states \& situations. Paris: OECD.

David, A. \& Nanes, S., 2011. The women's quota in Jordan's municipal councils: international and domestic dimensions. Journal of Women, Politics \& Policy, 32(4): 275-304. 
Demographic \& Health Surveys (DHS). 2013. Jordan Population and Family Health Survey 2012.

Accessed June 2018. https://dhsprogram.com/pubs/pdf/FR282/FR282.pdf

Domingo, Pilar \& Rebecca Holmes. 2013. Gender Equality in Peacebuilding and Statebuilding, London: ODI

Ehteshami, Anoushiravan. 1999. 'Is the Middle East democratizing?' British Journal of Middle Eastern Studies 26(2): 199-217.

Freedom House. 2016. 'Why Is Jordan Backsliding on Gender Equality?', https://freedomhouse.org/blog/why-jordan-backsliding-gender-equality

Goldenziel, Jill. 2012. "Veiled Political Questions: Islamic Dress, Constitutionalism, and the Ascendance of Courts." American Journal of Comparative Law 61(1) 15: 1-50.

Hirblinger, Andreas T., \& Claudia Simons. 2015. 'The good, the bad, and the powerful:

Representations of the 'local' in peacebuilding.' Security Dialogue 46, no. 5 (2015): 422-439.

Hutchings Kimberly. 2013. 'Liberal quotidian practices of world ordering.' In: Dunne, T \& Flockhart T Liberal world orders. Oxford: Oxford University Press.

Heydemann, Steven. 2007. 'Upgrading authoritarianism in the Arab world'. Saban Center for Middle East Policy at the Brookings Institution.

Al-Jazeera Net. 2009. 'Islamiyyu al-Urdun Dad ‘CEDAW' wa ma Haquq al-Mar’a (Jordanian Islamists against CEDAW and with women's rights, 27 April 2009.

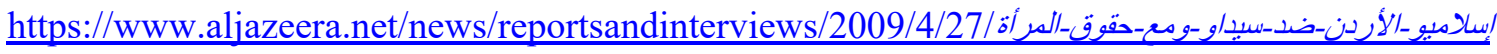


Jad, I., 2003. The 'NGOization'of the Arab women's movements. Al-Raida Journal, 38-47.

Charbel, Ghassan, 'Interview with his Majesty King Abdullah II with Al-Hayat', 22 March 2014, Available as of July 2019 at: http://www.jordanembassyus.org/speeches/interview-his-majestyking-abdullah-ii-al-hayat

King Abdullah, 2013. 'Making Our Democratic System Work for All Jordanians' (Discussion Papers, January 16, published on King Abdullah's official website).

Lorch, Jasmin \& Bettina Bunk. 2016. 'Gender Politics, Authoritarian Regime Resilience, and the Role of Civil Society in Algeria and Mozambique.' GIGA-German Institute of Global and Area Studies, Working Paper 292.

Lucas, R.E, 2003. Deliberalization in Jordan. Journal of democracy, 14(1), 37-144.

Lust, Ellen, Sami Hourani, \& Mohammad El-Momani. 2011. 'Jordan Votes: election or selection?' Journal of Democracy 22(2): 119-129.

Mac Ginty, Roger, 2011. International Peacebuilding and Local Resistance, Hybrid Forms of Peace, Palgrave Macmillan.

Martínez, José Ciro. 2017. ‘Jordan’s self-fulfilling prophecy: the production of feeble political parties and the perceived perils of democracy.' British Journal of Middle Eastern Studies 44(3): 356-372.

McInerney, Stephen \& Cole Bockenfeld, 2016. 'The Federal Budget and Appropriations for Fiscal Year 2017: Democracy, Governance, and Human Rights in the Middle East,' Project on Middle East Democracy. http://pomed.org/pomed-publications/fy17-budget-report/. 
El Muhtaseb, Lamis, Nathan J. Brown, \& Abdul-Wahab Kayyali. 2016. 'Arguing about Family Law in Jordan: Disconnected Spheres?' International Journal of Middle East Studies 48(4): 721-741.

Muriaas, R. L., Tønnessen, L., \& Wang, V. 2013. 'Exploring the relationship between democratization and quota policies in Africa'. In Women's Studies International Forum. 41: 89-93.

Nanes, Stephanie. 2003. 'Fighting honor crimes: Evidence of civil society in Jordan'. The Middle East Journal 57(1): 112-129.

NCFA. 2008. Violence Against Women in Jordan, Factsheet. Accessed June 2018:

http://ncfa.org.jo:85/NCFA/sites/default/files/publications/violence-against-women-jordan-factsheet.pdf

OECD. 2013. Gender and Statebuilding in Fragile and Conflict affected States: Policy Guidance. Accessed June 2018: https://www.oecd.org/dac/conflict-fragilityresilience/docs/gender statebuilding.pdf

Ottaway, Marina. 2003. 'Democracy challenged' The Rise of Semi-Authoritarianism, Washington DC.

Rice, Condoleezza, 2006. 'Transformational Diplomacy' (Speech delivered to Georgetown University on 18 January 2006). https://2001-2009.state.gov/secretary/rm/2006/59306.htm

Sabaratnam Meera. 2013. 'Avatars of Eurocentrism in the critique of the liberal peace.' Security Dialogue 44(3): 259-278.

Samadi, Tamer, Al-. 2013. 'Jordan's Prime Minister: King will Delegate some Powers', trans. Pascale Menassa, Al-Hayat, 18 January 2013, http://www.al-monitor.com/pulse/politics/2013/01/kingpowers-king.html 
Sharp, Jeremy. M. 2018. Jordan: Background and U.S. Relations, Congressional Research Service.

Schuetze, Benjamin. 2018. 'Marketing parliament: The constitutive effects of external attempts at parliamentary strengthening in Jordan,' Cooperation and Conflict 53(2): 237-258.

Tripp, Aili Mari. 2013. 'Why Do Authoritarian Regimes Adopt Quotas: Lessons from African Cases.' In Third European Conference on Politics and Gender, Barcelona, Spain, March (21-23).

Tripp, Aili Mari. 2015. Women and power in post-conflict Africa. Cambridge University Press.

Wiktorowicz, Quintan. 2000. 'Civil society as social control: State power in Jordan'. Comparative politics, 33(1): 43-61.

Wilde, Gabriele, Annette Zimmer, Katharina Obuch, \& Isabelle-Christine Panreck, eds. 2018. Civil Society and Gender Relations in Authoritarian and Hybrid Regimes: New Theoretical Approaches and Empirical Case Studies. Verlag Barbara Budrich. 